\title{
Analysis of the Intensity of Communication and Coordination of Government Officials on Twitter Social Media during the Covid-19 Handling in Indonesia
}

\author{
Muslimin Machmud ${ }^{*}$ \\ Bambang Irawan ${ }^{2}$ \\ Kisman Karinda ${ }^{3}$ \\ Joko Susilo1 \\ Salahudin $^{4}$

\begin{abstract}
${ }^{1}$ Department of Communication Science, Universitas Muhammadiyah Malang, Indonesia
${ }^{2}$ Department of Public Administration, University of Mulawarman, Indonesia

${ }^{3}$ Department of Government Studies, Universitas Muhammadiyah Luwuk, Indonesia

${ }^{4}$ Department of Government Studies, Universitas Muhammadiyah Malang, Indonesia

*Corresponding Author
\end{abstract}

DOI: https://doi.org/10.36941/ajis-2021-0o87

Abstract

The aim of this study is to explain government officials' communication and coordination intensity on twitter social media while handling the Covid-19 pandemic in Indonesia. This research uses a qualitative content analysis approach towards the official Indonesian government official's account. The result showed a developed communication and intensive coordination between President Jokowi and the team, in attempt to properly accelerate the handling process. Furthermore, this activity was also achieved with a number of governors. The presidency aimed to build the commitment of central and local government officials, and jointly support the policy implementation to properly manage Covid-19. These communication and coordination activities positively impacted on the high attention of local governments to accelerate the handling in a number of regions. However, the study limitations include the use of Twitter social media data, characterized by the inability to reveal performance of government officials. Therefore, subsequent research is expected to adopt a triangulation analysis approach to data on twitter social media, online media, official government reports, and information from trends in Indonesian cases.

Keywords: Covid-19, Communication, Coordination, Government Officials, Social Media, Governor and President

\section{Introduction}

Disaster management requires the speed and accuracy of government to formulate decisions and implement policies to facilitate the expeditious and precise resolution of crisis (Lestari et al., 2020). This efficient control is highly dependent on the availability of information concerning the ongoing misfortunes (Pennycook et al., 2020). Meanwhile, data obtainability depends on the alacrity employed 
by the government in communication and coordination with all related parties, including discussions and dialogues regarding problems encountered during disasters, therefore resulting in the formulations of ideas and management strategies (Lestari et al., 2020; Panagiotis Panagiotopoulos et al., 2014). The non-immediacy in determining policy decisions due to sluggishness portrayed by the government during critical situations is the current difficulty being discussed (Panos Panagiotopoulos et al., 2016b).

Previous researches revealed the correspondence and organization of the central and local Indonesian governments during the control of Covid-19 outbreak was appalling, resulting in a failure to prevent the viral spread in the country (Setiati \& Azwar, 2020). Despite the autonomy of policy determination by ministries at the federal division, several departmental rules coincided (Salahudin, 2020). This overlap was illustrated by the restriction of public transportation use by The Health Ministry to promote social distancing, while the Transportation Ministry encouraged the process on the grounds of economic sustenance (Setiati \& Azwar, 2020). Another instance was the implementation of the social assistance policy by the Social Affairs Department for persons displaced by the pandemic, the inclination towards diversion of funds for the outbreak management program by the Villages and Disadvantaged areas Ministry, while there were pending guidelines for resource disbursal by the Finance Ministry(Machmuda et al., 2020). Subsequently, the disagreements amongst these offices elicited public chaos amid the Covid-19 pandemic (Abidah et al., 2020; Djalante et al., 2020; Harapan et al., 2020). In addition, there were disagreements involving central and local governmental regulations, as the federal body prohibited the execution of the lockdown policy, while several local governments had implemented the exercise.

According to earlier investigations, preparations during the Covid-19 pandemic in Indonesia had not been adequately publicized by administrative officials through social media outlets, particularly twitter. In fact, the study of crisis management through social platforms has proven to be an essential move, as this entails the potentials of exposing the inherent challenges of stakeholders in handling crisis. There also lies a tendency to provide solutions to these problems through interactive technologies, especially in the face of a pandemic. Therefore, the aim of this study was to explore government communication and coordination through twitter during the Covid-19 pandemic in Indonesia. The research inquiries comprising the government officials' intensity in preparing to handle the outbreak, and the attentive emphasis expressed during the disease management were explained through a qualitative analysis of administrative officials' twitter content by employing the Nvivo 12 plus software.

\section{Literature Review}

\subsection{Social Media as a Means of Public Communication}

Information technology has become an inseparable aspect of modern human life, and a product of this phenomenon is social media, used as the most popular means of communication and interaction (Alexander, 2014). Social media promotes effortless communication, and supports the achievement of common goals and interests through an impact on societal network formation (Gundecha \& Liu, 2012). Furthermore, social media users are able to convey information to the public, through text messages, images, or posters, and obtain responses capable of being discussed by several parties (Gui et al., 2017). The transfer of information through these platforms are accessible and reacted to by audiences with various perspectives (Ewing et al., 2019). These recipients tend to exhibit positive sentiments and consider the circulated news as important, or as negative and a cause for public debate and argument (Hadi \& Fleshler, 2016).

Social media use needs to be aimed at the creation of communicative and interactive techniques to promote the attainment of mutual interests, depending on the understanding and intelligence of the users (Ceron, 2017). This important factor affects the positive roles of social media, as smart creators and disseminators produce good quality content, and generate favorable values for the public (Vos \& 
Buckner, 2016). Furthermore, earlier studies revealed organizations become inseparable from work environments when social platforms are utilized, and also benefit from encouragements to human resource capabilities and skills (Roblek et al., 2013). Institutions employ interactive technologies to facilitate communication, coordination and collaboration, boost the implementation of roles and functions, and further encourage the accomplishment of organizational visions (Cho et al., 2014). In this globalization era, both private and public establishments are making attempts to modify company management from offline to online-centered (Kimmel \& Kitchen, 2014). Furthermore, the purpose of social media use as a governance platform is to expedite information transfer and communication relevant to the attainment of business objectives (Panagiotis Panagiotopoulos et al., 2014). Also, firms generate advantageous benefits, including the formulation of fast and precise policies, optimization of time and energy, cost efficiency, as well as rapid response to internal and external glitches through the application of this tool (Zeng et al., 2017).

Numerous studies illustrate the employment of interactive technologies by establishments demonstrate better performance than those using conventional methods as management platforms (Muninger et al., 2019; Panagiotis Panagiotopoulos et al., 2014; Pickard G. Picard, 2017). These channels assist swift understanding of difficulties and public opinion, aid adaptation to existing industrial transformations, and accelerate the creation of tactical techniques to react to these budding issues (Avery, 2017; Osterrieder, 2013). Therefore, public organizations in various countries are making efforts to appoint social media as a means of interaction and collaboration to appropriately promote the effectiveness and efficiency of performing organizational duties as well as other functions in all public affairs (Avery, 2017; Gintova, 2019; Hadi \& Fleshler, 2016; Osterrieder, 2013; Reuter et al., 2018).

\subsection{Roles of Social Media in disaster Management}

Social media plays an important role in mid and post-disaster management. This is achieved through listening, integration, collaborative networking, creating cohesion, fundraising, providing monitoring tools and research media (Avery, 2017).Therefore, the government is empowered with the ability to obtain accurate information and take rapid action (Lestari et al., 2020; Panos Panagiotopoulos et al., 2016b). These platforms aid effective communication and coordination, required for response and recovery programs to run smoothly, as further explained below (Panos Panagiotopoulos et al., 2016b).

First, listening function: All government units as well as the community use social media to discuss, exchange information and take appropriate disaster control actions. Numerous studies revealed this accelerates decision making. Also, authorities use social media as a means to coordinate the public and other stakeholders (Zhu et al., 2017). Second. Monitoring: Social media is used to monitor difficulties during catastrophes. In addition, both the government and the community use these platforms to find out the number of victims, infrastructure, and public reactions to disaster management policies (P. Singh et al., 2020). This way, authorities ensure all command units and citizens play an active role in program implementation at all times. Also, each party has the ability to monitor the schemes' effectiveness.

Third, social integration: Social media is important in fostering mutual cooperation during disaster management. The government uses these platforms to invite and urge central and regional units as well as the entire public to unite, especially during recovery stage (Zeng et al., 2017). As a result, authorities are able to oversee this solidarity, swiftly formulate any necessary encouragement or adjustment policies, and in turn, create social capital for rapid and accurate disaster management. Fourth, Collaborative networking: Social media functions as an avenue to form networks, support coordination for rapid, effective and easy disaster management, with minimal risks (Saleh \& Yusmanizar, 2019). The government, especially at the central level, uses these platforms to engage all units, including the community to ensure collaboration and support towards policy implementation. This alliance is necessary for effective communication.

Fifth, creates social cohesion: social media serves as a means to build cohesive strength among all government units (both at the central and regional levels), to foster unity in catastrophe management. 
This condition provides good control in mobilizing, directing and uniting all state resources for rapid and effective catastrophe regulation (Liu et al., 2016). Previous research disclosed the tendency for disaster control policies conveyed by authorities through these platforms to receive mixed responses from all parties. However, the reactions observed strengthens the government to consolidate units for this purpose. Sixth, fundraising tool. One significant role of social media is to serve as a channel to raise funds for various purposes, including disaster management. Several government agencies leverage this platform to source for funds for their operations (Bernaoui et al., 2019; Nazaruddin, 2020). In this case, fundraising appeals are dispatched to all government units and other communities where most rapid responses are recorded. Furthermore, the use of social media by certain countries provides an effective and efficient technique in generating funds for disaster management, both during and after the tragedy. Seventh, research media. Social media also helps to implement research on disaster from various perspectives, where the information are used to provide comprehensive support on the subject matter as well as other research topics (Kim \& Hastak, 2018; Qazi et al., 2017). Therefore, researchers need to show strong ability in obtaining and analyzing the massive available data.

The aforementioned background shows the importance of social media in managing disasters. Previous studies have shown certain countries employ social media as a viable method of communication and crisis management (Panagiotis Panagiotopoulos et al., 2014). This platform helps to provide and disseminate information for proper understanding and also reduces the risk of public panic. Furthermore, the application of social media also aid government to formulate accurate and timely disaster management policies and ensure adequate implementation (Pohl et al., 2015).

\section{Research Methods}

This study applies qualitative approach to analyze social media content, particularly Twitter, with the aim to describe the relationship between actors in the fight against Covid-19 pandemic in Indonesia. Based on this analysis, proper interactions and networks of central and local government officials to formulate and implement policies to manage the outbreak are comprehended. The collaborative efforts between all stakeholders are measured in terms of the intensity of communication and coordination among government officials. This provision is further analyzed based on the synergized Twitter content of individual public officer, where higher content similarity reflects greater value between communication strategies in managing the pandemic, and hence, the level of attention (Linda Lai \& To, 2015; Nursing \& Kyng, 2008).

The analytic stages include, first, to determine the actors known as the object of analysis, in terms of the names of the selected government officials (Himelboim et al., 2017). However, certain important criteria involving actors as the object of analysis, include government officials empowered to determine and implement workable policies, administrators in charge of territories with increased positive viral cases, prone areas, or centres of public attention, and also public officials with active twitter accounts and high engagement.

Second, data collection on Twitter account (Cinelli et al., 2020). In this case, the researcher captures the social media content owned by the selected government officials. These are the various statements on their respective twitter handles, and are further classified based on content similarity. In addition, data collection is achieved using social media data analysis software, where researchers are required to filter, select, and categorize the obtained data.

Third, categorization and data analysis of individual twitter content (Getchell \& Sellnow, 2016). This appears as the most critical stage and therefore, requires the ability to interpret the data obtained from each Twitter account. In this case, researchers play an important role in classifying and linking data between each account, interpreting statements, discussing actor relationships and personal views, developing scientific justifications, and actor networks indicated by communication intensity and interaction between government officials on pandemic issues.

Data / online news media are also applied to support and reinforce social media data, particularly Twitter. These publications originate from various Indonesia's trusted and influential online media, 
including kompas.com, tempo.com, detik.com, and republika.com. However, social media content using Twitter, is strongly employed as a primary data and potentially serve as reference for further clarification, description, analysis, and arguments, while online news media act as support frameworks, and also aim to enrich research analysis to draw proper conclusions. The value of communication intensity and coordination of government officials on social media is described with arguments built on data, reinforced by online news media, and elaborated on previous research findings (Linda Lai \& To, 2015).

Nvivo 12 plus software is used to analyze the social media (Twitter) content. This tool shows the ability to capture twitter content data of the selected government officials (Brandão, 2015). In applying the software, the stages involve, first, installing the Nvivo 12 plus software for windows and NCapture extension on Google Chrome in order to acquire twitter content and import the data from the results. Comprehensively, the steps include, activating the NCapture in the Nvivo 12 plus work screen, management of twitter content files on the Nvivo 12 plus work screen, auto-code Twitter content to generates themes, visualization of themes in the form of charts, actor network analysis with the Sociogram Nvivo 12 plus feature, analysis of Twitter content similarity with cluster analysis features, and the Pearson correlation and coefficient formula. The resulting data are further interpreted and categorized to produce adequate conclusions targeted towards solving the research problem.

\section{Result and Discussion}

\subsection{Intensity of Central and Regional Communications and Coordination}

Table 1 displayed the high intensity of interaction and synchronization among President Jokowi, the Governors and the Official Team for Covid-19 management (GT Covid RI) as relevant stakeholders. Subsequently, with 1 as the maximum value, the number 0.5 breached into the high category to illustrate the strong similarity between the President and related actors' Twitter topics. With relations to content analysis, this was interpreted as the degree of ongoing communication and coordination, and confirmed existent efforts to foster synergy between government ranks as the chief solution for the pandemic control in Indonesia. This cooperation was mandated in integrated policies where rigorous preparations occur to facilitate distinct and focused operational methods. Furthermore, harmonious regulations between the federal and regional levels to prevent the viral spread and minimize socioeconomic implications were required to be confirmed by the Head of State.

Table 1. Intensity of Communication and Coordination of President Jokowi, Governor and the Covid 19 Task Force

\begin{tabular}{llc}
\hline President & Governor and Official Team & Pearson correlation coefficient \\
\hline President-Jokowi & Governor-North Sumatra & 0.868092 \\
\hline President-Jokowi & Governor-Central Java & 0.860384 \\
\hline President-Jokowi & Governor-Jatim & 0.852013 \\
\hline President-Jokowi & Governor-West Java & 0.83221 \\
\hline President-Jokowi & Governor-DKI & 0.809746 \\
\hline President-Jokowi & Governor-South Sulawesi & 0.779419 \\
\hline President-Jokowi & GT Covid 19 RI & 0.776884 \\
\hline President-Jokowi & Governor-NTB & 0.775882 \\
\hline
\end{tabular}

Source: Results from Cluster Analysis with Nvivo 12 Plus.

Collaborations with the federal government was absolutely necessary during the pandemic management. This was exemplified by the demand for governmental support expressed by North Sumatra to surmount the effects of the daily workers' diminishing income, particularly the motorcycle, 
taxi and pedicab drivers, predicted to decline to $44 \%$. Also, Central, East, and West Java, DKI Jakarta and South Sulawesi were areas with the highest disease cases and demonstrated need for central government support, regarding assistance with medical equipment and social safety net programs. The workers in NTB were also expected to experience a decrease in earnings of approximately $25 \%$. Table 1 showed the several similarities and shared perceptions between the Central and Local governments, along with the Indonesian Covid-19 Task Force. This mutuality was a sign proving integrated collaboration was key in the successful management of the outbreak. The Federal Government possessed the highest authority in the viral spread control and was required to involve other areas where the cases were more frequent. This process was possible provided a shared perception in contending with the virus existed.

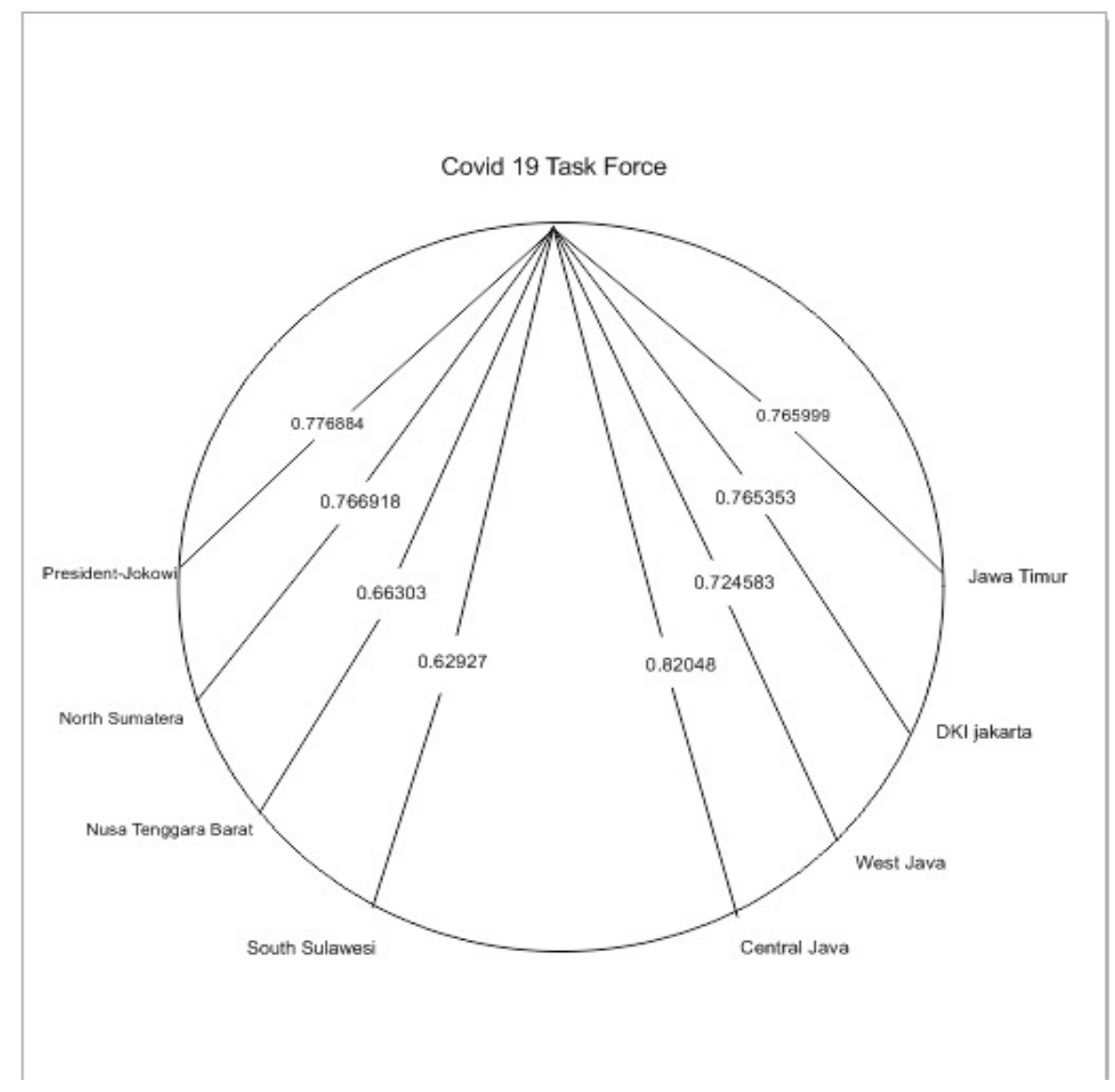

Figure. Intensity of Communication and Coordination of President Jokowi, Governor and the Covid 19 Task Force

Source: Results from Cluster Analysis with Nvivo 12 Plus.

A similar situation of the analogous Tweets was observed in fugure 1. Meanwhile, the RI Task Force is an institution accountable to the president with the aim of performing rapid, precise, focused, integrated, and synergistic interactions between ministries, agencies and local governments. The group became the official reference institution for the leaders to operate, and the likeness in social media content was therefore expectedly high. 


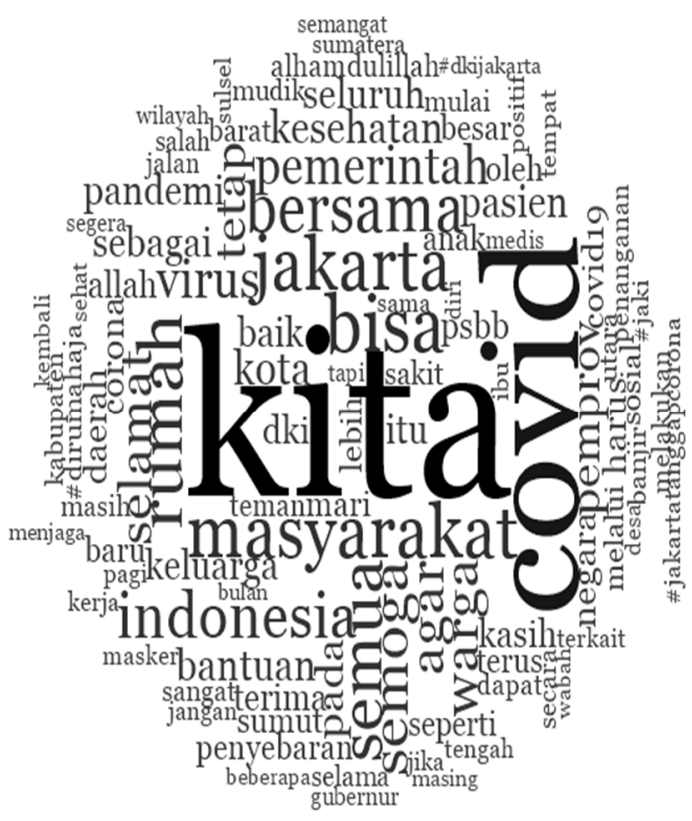

Figure 2. Discussion Issues in Communication and Coordination of President Jokowi, the Governor and the Covid-19 Task Force

Source: Results from Cloud Analysis with Nvivo 12 Plus.

Figure 2 shows the Chief of Staff's efforts to strengthen the country's togetherness during the disease outbreak. The words "KITA" and "COVID" were the most frequent expressions communicated to the Governors and Tasks officers to convey the nature of the viral disease as "a national problem solely resolvable through intensive collaboration among all levels of government." These statements also expressed crisis management efforts aimed at enhancing relevant stakeholders' confidence in the government as representatives of the peoples' interests. Also, cooperation was promoted as a relevant action, particularly in a multisectoral crisis as the outbreak. The recurrent word "KITA", meant all parties cooperated for national benefit, while relinquishing sectoral egos resulting from obstacles to the effectiveness of disaster management. These hindrances were products of political or economic motives subsequently degenerating into obstacles to the disaster management efficiency in Indonesia.

\subsection{The Center of Actor's Attention during Talks in Communication and Covid-19 Coordination}

Graph 1 shows the different level of attention exhibited by each actor. This was due to the variation in educational narrative focus, despite similarity in spirit, including engulfing the Covid-19 Curva. In addition, DKI Jakarta is also focused on the campaign " Al of us " required to educate Jakarta residents, in an attempt to foster obedience and discipline with the stipulated health protocol rules. This is observed especially through the implemented Large-Scale Social Restrictions (PSBB). The phrase "All of us" indicates the exhibition of compliance by all to a common interest, and is strengthened by the expression, "we can do" (15.23\%). Also, West Java (19.52\%) and East Java (23.3\%) focus on Covid-19 transmission, with emphasis on the extent of danger faced for community survival. These two regions are known to have a high incidence rate and have become a hotspot for local transmissions. 


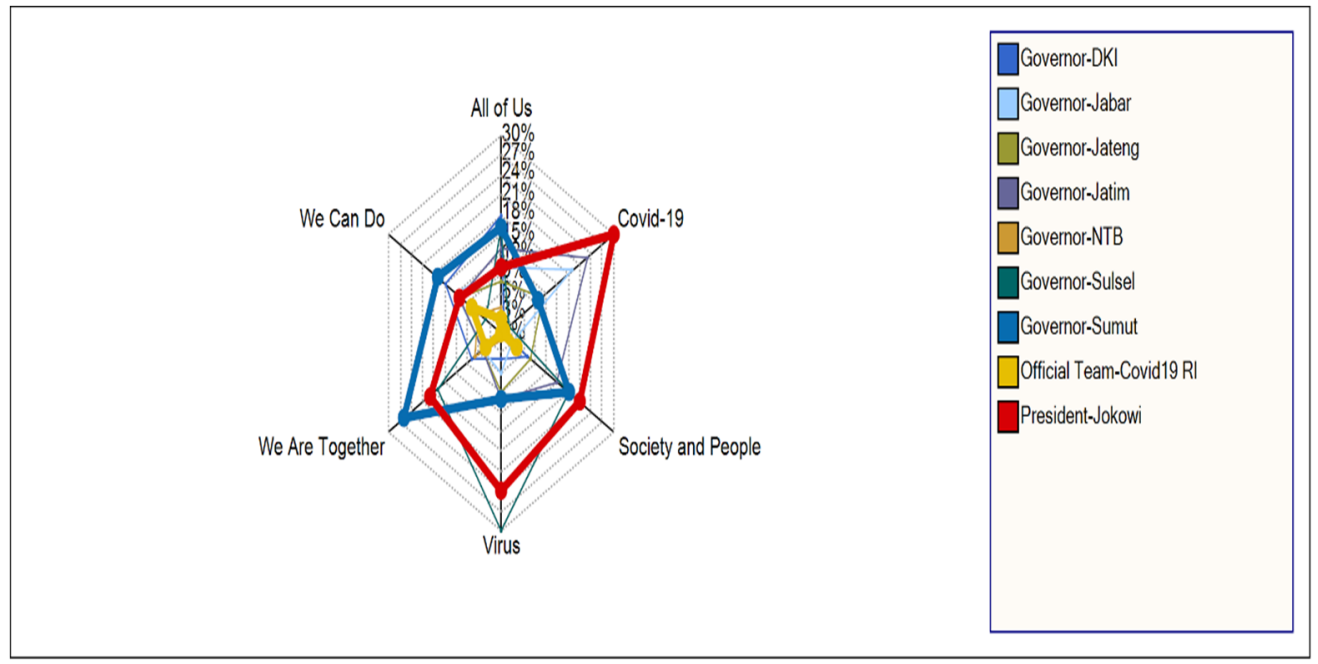

Graph 1. The Center of Actor's Attention to the Content of Talks in Communication and Covid-19 Handling Coordination

Source: Results from Crosstab Analysis with Nvivo 12 Plus.

Jokowi (30\%) performed a similar study, and explained the economic and social impacts incurred as a result of Covid-19. Furthermore, several coping strategies were observed to have been implemented. The we can do campaigns (11.8\%) organized in Central Java to fight Covid-19 (11.4) was aimed at arousing the optimism of Central Java indigenes in the combat against the virus amid existing limitations. The transmission chain, for example, is possibly suppressed by the individual's willingness to stay at home or strictly implement health protocols in life. In addition, a similar pattern was observed by the Covid-RI Group (8.7\%). Meanwhile, North Sumatra (26.85\%) and NTB (7.61) focused on "We Are Together" as an important handling instrument to convey the message on cooperation, help and sacrifice of all parties. The South Sulawesi region emphasized on viruses (30.77\%) to explain the dangers of Corona as a virus and measures appropriated by the government to overcome.

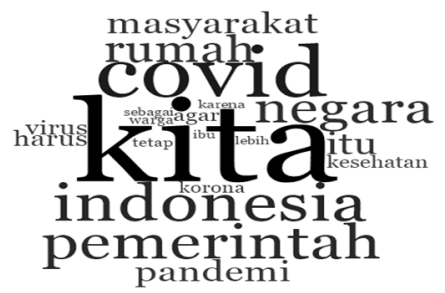

Figure 3. President Jokowi's Attention in Communication and Covidence Handling Covid 19 Source: Results from Cloud Analysis with Nvivo 12 Plus.

Figure 3 shows the existence of 3 important keywords in Jokowi's Twitter narrative, including us, Covid and the government. Also, the word "KITA" was emphasized to urge, invite and unite all local government parties (governors) and the public against the pandemic. This collaboration was ensured for the benefit of all Indonesians. Therefore, the cooperation and collaboration of all parties is symbolized in our word, and Covid-19 is considered to be very dangerous because of the fast spread, and tracing difficulties. However, serious handling and the compliance of all parties is needed in the 
aspect of behavior, according to established health protocols. Jokowi, as the highest holder of power in government, and also the main person in charge of handling the pandemic, ought to convey several explanations regarding the policies for proper management to be implemented. This is performed as a form of government's seriousness.

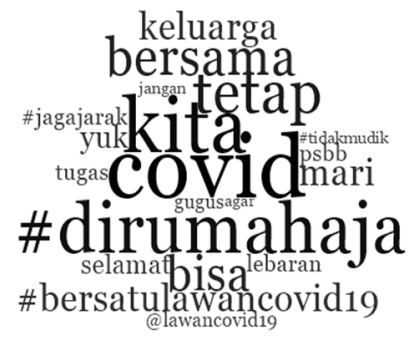

Figure 4. Attention of the Task Force in Communication and Covidence Handling Covid 19 Source: Results from Cloud Analysis with Nvivo 12 Plus.

Figure 4 shows the three main concerns of the Indonesian Task Force in handling the pandemic, including "Covid, Kita, and \#dirumahaja". This institution formed Indonesian government facilitated the coordination of activities between institutions, in an effort to prevent and mitigate the disease impacts new in Indonesia. Therefore, the massive socialization of related information was performed very naturally, as observed with the availability of detailed information about Covid, and how to break the distribution chain. Furthermore, the Indonesian Task Force, in line with Jokowi, also explained all of us (government and society) as the main key to proper management. This is effectively conducted by staying and performing activities at home to inhibit spread, experienced mainly after direct contact in public spaces.

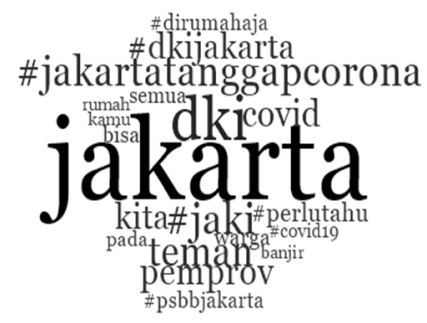

Figure 5. The Attention of the Governor of DKI in Communication and Covidence Handling Covid 19 Source: Results from Cloud Analysis with Nvivo 12 Plus.

Figure 5 shows the 3 frequently conveyed (focus) keywords identified in the Twitter account of the Governor of DKI Jakarta. Firstly, Jakarta was coined to demonstrate all activities performed by the Government, the public and the private sector in supporting and handling the pandemic. This was also commonplace, considering Jakarta as an administrative area often referred to as the local governments' identity, known to be substantially responsible for Covid-19 management. This parameter highlighted in the current aspect of politics is possibly interpreted as a show of strength for Governor Anies, assumed to have an approach different from the Central Government. The DKI Jakarta Province has played a major role in resolving this crisis, especially due to the status as region with the highest incidence. Secondly, DKI was an attribute of the inherent authority privileges, characterized by a special relationship with the first point, thus considered reasonable to mention often. Thirdly, Friends 
"Teman" was used an expression towards the community's contribution. This was also selected due to the symbolism of greater familiarity, distance and millennial impression.

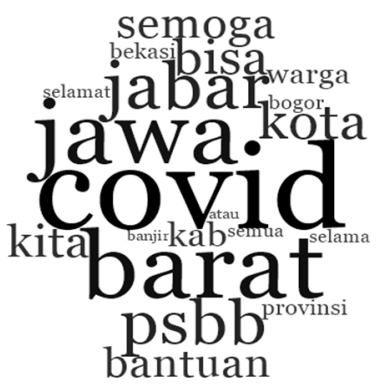

Figure 6: West Java Governor's attention to Covid-19 coordination and communication. Source: Results from Cloud Analysis with Nvivo 12 Plus.

West Java is one of the five Indonesian regions with the most covid-19 cases. Figure 5 shows the governor's twitter account (@Ridwan Kamil) is used to convey basic information about the disease's transmission as well as preventive measures and the province's name is often mentioned in this communication. This is because the disease's management is the provincial taskforce chairman's duty. Furthermore, this platform is used to elucidate response, rationalization and development programs. The words "Javanese" and "western" appear even more frequently than West Java, but are already implied by the region's name, and therefore, not counted. The other keyword is "PSBB", a policy created to stop Covid-19's spread in the district. This program's effectiveness depends on the authorities' socialization. Through this social media platform, awareness is increased in a bid to flatten the pandemic's curve.

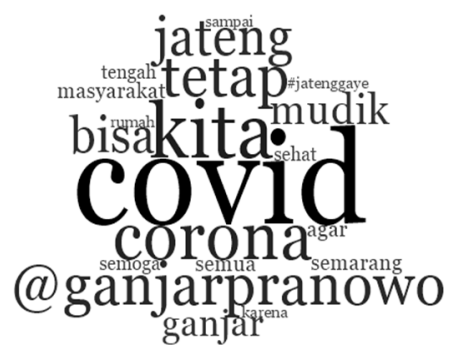

Figure 7: Central Java Governor's attention to Covid-19 coordination and communication.

Source: Results from Cloud Analysis with Nvivo 12 Plus.

As the Governor of Central Java, Ganjar Pranowo actively uses twitter to convey information about Covid-19. Figure 6 shows the virus has been socialized and the need for comprehensive reports on the disease's dangers, impacts, transmission, prevention and management policies as well as public participation requirement. Furthermore, "Kita" is used to signify solidarity among residents while complying with safety protocols. This word indicates the pandemic is a shared responsibility requiring awareness and cooperation from all parties. The virus' more popular name, "Corona" is often mentioned as well. 


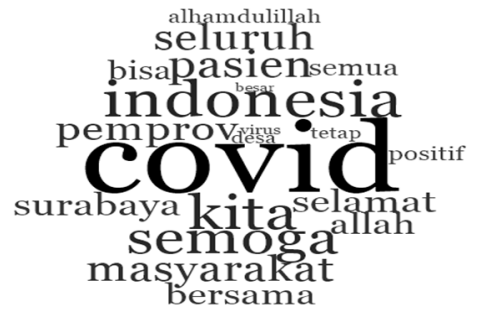

Figure 8: East Java governor's attention to Covid-19 coordination and communication.

Source: Results from Cloud Analysis with Nvivo 12 Plus.

East Java is currently the region with the most Covid-19 cases after DKI Jakarta. This was predicted due to the residents' high mobility. Hence, the governor's twitter account (figure 8) serves a very important purpose. The pandemic has become a major concern among the inhabitants, as a result, there is a need to convey all relevant information including government management policies and public participation requirements. Furthermore, the words "Indonesia" and "we" are often used to imply a joint effort in saving the country and the need to comply with implemented health protocols.

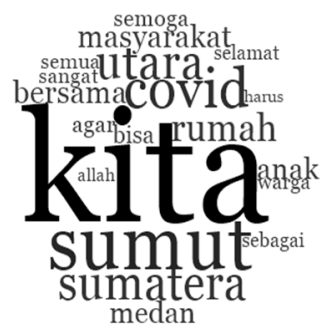

Figure 9: North Sumatra governor's attention to Covid-19 coordination and communication. Source: Results from Cloud Analysis with Nvivo 12 Plus.

Figure 9 indicates the governor makes use of three key words and all response policies as well as recommendations issued by the Provincial government are in accordance with the residents' common interest. Therefore, compliance, solidarity, and cooperation are expected from the community. In addition, the word "North Sumatra" is mentioned to convey developments in the region's corona virus cases, management policies, and encourage public participation in the province. Also, "Covid" is used to emphasize the dangers presented by the pandemic as well as preventive measures.

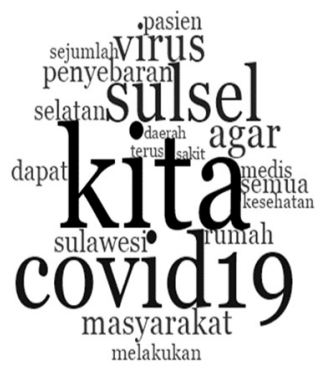

Figure 10: South Sulawesi Governor's attention to Covid-19 communication and coordination Source: Results from Cloud Analysis with Nvivo 12 Plus. 


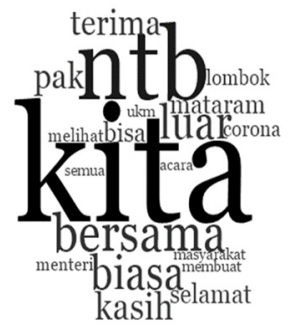

Figure 11: The NTB Governor's Attention to Covid-19 communication and coordination Source: Results from Cloud Analysis with Nvivo 12 Plus.

Figure 10 indicates this is one of the regions most affected by Covid-19 in Indonesia. The governor's twitter account (@Nurdin Abdullah) focuses on three words, "Covid-19", "Kita" and "South Sulawesi" as efforts are made to show the pandemic is a common problem and requires action from the government and community. The first word is used while educating the public to prevent the disease's transmission through complying with health protocols and to foster optimism even in this difficult time. Also, the province's name is mentioned to convey the prevention and response strategies carried out by the regional authorities and task force. This aims to show residents the government is doing everything possible to prevent the virus' spread. According to Figure 11, the Governor's twitter account (@Nusa Tenggara) uses three keywords, "Kita”, “NTB”, and "together" to indicate the pandemic is a general problem and requires the inhabitants' enthusiasm, cooperation, as well as optimism to be properly handled.

\section{Discussion}

An essential finding of this study is that President Jokowi plays an active role in building communication and coordination with the Covid-19 handling task force and several governors in Indonesia whose aim is to accelerate the handling of Covid-19 in Indonesia (Panos Panagiotopoulos et al., 2016a). President Jokowi's active role has resulted in regulations for handling Covid-19, including social distancing regulations, implementation of PSBB policies, and new normal policies. Besides, President Jokowi also tried to urge the public to fight Corona. President Jokowi always emphasized that the handling of Covid-19 needs to be done through cooperation and synergy of all parties (Ewing et al., 2019; Reuter et al., 2018). President Jokowi uses the word "Kita" as a sign of unity for all parties in the handling of Covid-19 in Indonesia. President Jokowi's active role in handling Covid-19 emphasized that President Jokowi, as head of state and government, paid great attention to handling Covid-19 (Alexander, 2014).

President Jokowi's active role is supported by the Task Force's active role for the Acceleration of Handling Covid-19, a particular agency for handling Covid-19 formed by President Jokowi. As an executing agency for Covid-19 handling policies, the task force seeks to build intensive communication and coordination with President Jokowi and several governors in Indonesia (Gui et al., 2017). The Covid-19 handling task force's communication content has similarities and similarities to the communication content of President Jokowi, which confirms that the Covid-19 handling task force positions itself as a channel of communication and coordination for stakeholders including ministries, police, local governments, and society (Jong et al., 2016). Nevertheless, the intensity of attention of the Covid-19 handling task force to issues of handling Covid-19 was not higher than the attention of President Jokowi, and several governors analyzed in this study (Lestari et al., 2020). The low-intensity value of the task force's attention to handling Covid-19 confirms that the Covid-19 handling task force has not been able to build synergy with several governors in Indonesia, which then results in overlapping policies on handling Covid-19 between the central government and local governments, 
even overlapping policies between ministries (Zhu et al., 2017). The overlap of policies in handling Covid-19 marks the policy's failure in building good crisis communication and coordination (L. Singh et al., 2020).

President Jokowi's active communication and coordination have influenced governors' active role throughout Indonesia in supporting the acceleration of handling Covid-19 in their respective regions. Several governors built communication and active coordination with President Jokowi and the Covid19 Handling Task Force, which then influenced the formation of similar communication content between President Jokowi and several governors (Jong et al., 2016). The communication content of several governors depicts President Jokowi's communication content, namely communication that emphasizes the call to be alert to COVID, unite against Corona, together we can, support the implementation of PSBB policies, and stay at home (Gui et al., 2017). The similarity of communication content shows that President Jokowi and several governors have the same concern in dealing with Covid-19 in Indonesia, which confirms that the governor is trying to implement the policy for handling Covid-19 made by the central government (Alden \& Alden, 2017; P. Singh et al., 2020).

The findings above was revealed that several governors have the same communication content with the central government. However, not all governors have the same concerns and policies as the central government. The Governor of DKI Jakarta, for example, has different concerns and policies for handling Covid-19 from the central government. This difference in attention was influenced by poor communication and coordination between President Jokowi, the Covid-19 Handling Task Force, and the governor of DKI Jakarta. In the early days of Corona becoming a public concern in Indonesia, the Governor of DKI Jakarta and the Central Government had different views on the Covid-19 problem. At that time, the Governor of DKI Jakarta implemented a lockdown policy (Pickard G. Picard, 2017). However, the policy was canceled by the central government because, according to the central government's view, Corona has not and will not enter Indonesia (Ihsanuddin, 2020). Therefore the DKI Jakarta government does not need to implement a LockDown policy, which causes the public to panic and fear (Dewi Nurita, 2020a). The central government then emphasized that local governments, including DKI Jakarta, are not authorized to make and implement a lockdown policy (Dewi Nurita, $202 \mathrm{ob}$ ). According to the central government, the Covid-19 problem is a national problem related to state defense and security affairs, which is the domain of the central government's authority (Pennycook et al., 2020; L. Singh et al., 2020). The policy conflict between the DKI Jakarta government and the central government has contributed to the government's failure to handle the spread of Covid19 in the DKI Jakarta area (Tempo, 2020).

\section{Conclusion}

This study shows government officials are intensively building communication and coordination to accelerate Covid-19 management in Indonesia. President Jokowi constantly communes with the virus' official management team to guarantee all government agencies are united and actively mobilized, both at the central and regional levels. This enables quick and precise action. In addition, the head of state keeps in touch with all the governors to ensure that crisis control policies are implemented and obeyed. This communication also ensures all local governments are committed to combating the virus across Indonesia. As a result, administration's officials pay more attention to Covid-19 management in the country and governors help to educate the public on the need to unite against the virus through compliance and discipline with regard to implemented health protocols.

This study confirms the communication and coordination pioneered by the president is a strategic crisis management step, and has caused public officials to jointly implement these control policies quickly and accurately. However, the limitations on Twitter use are invalidated by online media data, government programs and official reports, interviews, surveys, as well as observations. Subsequent research using the twitter triangulation approach and other data is required to fully determine Indonesia's present administration's communication and coordination performance in handling Covid-19. 


\section{References}

Abidah, A., Hidaayatullaah, Simamora, Fehabutar, \& Mutakinati. (2020). The Impact of Covid-19 to Indonesian Education and Its Relation to the Philosophy of “ Merdeka Belajar ." Studies in Philosophy of Science and Education, 1(1), 38-49. https://doi.org/https://doi.org/10.15408/sjsbs.v7i3.15104

Alden, C., \& Alden, C. (2017). Critiques of the Rational Actor Model and Foreign Policy Decision Making. Oxford Research Encyclopedia of Politics. https://doi.org/10.1093/acrefore/9780190228637.013.474

Alexander, D. E. (2014). Social Media in Disaster Risk Reduction and Crisis Management. Science and Engineering Ethics, 20(3), 717-733. https://doi.org/10.1007/s11948-013-9502-z

Avery, E. J. (2017). Public information officers' social media monitoring during the Zika virus crisis, a global health threat surrounded by public uncertainty. Public Relations Review, 43(3), $468-476$. https://doi.org/10.1016/j.pubrev.2017.02.018

Bernaoui, R., Ohly, P., Soergel, D., Bernaoui, R., Ohly, P., \& Soergel, D. (2019). Knowledge organization in the AgriFood sector in Algeria. Sharing information and communication through social media networks To cite this version: HAL Id: hal-02306618 Knowledge organization in the AgriFood sector in Algeria. Sharing information and.

Brandão, C. (2015). Qualitative Data Analysis with NVivo. Qualitative Research, 12(4), 492-494. https://doi.org/10.1080/14780887.2014.992750

Ceron, A. (2017). Social media and political accountability: Bridging the gap between citizens and politicians. Social Media and Political Accountability: Bridging the Gap between Citizens and Politicians, 1-236. https://doi.org/10.1007/978-3-319-52627-o

Cho, M., Schweickart, T., \& Haase, A. (2014). Public engagement with nonprofit organizations on Facebook. Public Relations Review, 40(3), 565-567. https://doi.org/10.1016/j.pubrev.2014.01.008

Cinelli, M., Quattrociocchi, W., Galeazzi, A., Valensise, C. M., Brugnoli, E., Schmidt, A. L., Zola, P., Zollo, F., \& Scala, A. (2020). The COVID-19 Social Media Infodemic. 1-18. http://arxiv.org/abs/2003.05004

Dewi Nurita. (2020a). Jokowi: Beruntung Pemerintah Pilih PSBB, Bukan Lockdown. Tempo.Co. https://nasional.tempo.co/read/1339664/jokowi-beruntung-pemerintah-pilih-psbb-bukan-lockdown

Dewi Nurita. (2020b). Jokowi Pilih Pembatasan Sosial Skala Besar, Tutup Opsi Karantina. Tempo.Co. https://nasional.tempo.co/read/1326017/jokowi-pilih-pembatasan-sosial-skala-besar-tutup-opsi-karantina

Djalante, R., Lassa, J., Setiamarga, D., Sudjatma, A., Indrawan, M., Haryanto, B., Mahfud, C., Sinapoy, M. S., Djalante, S., Rafliana, I., Gunawan, L. A., Surtiari, G. A. K., \& Warsilah, H. (2020). Review and analysis of current responses to COVID-19 in Indonesia: Period of January to March 2020. Progress in Disaster Science, 6, 100091. https://doi.org/10.1016/j.pdisas.2020.100091

Ewing, M., Men, L. R., \& O’Neil, J. (2019). Using Social Media to Engage Employees: Insights from Internal Communication Managers. International Journal of Strategic Communication, 13(2), $110-132$. https://doi.org/10.108o/1553118X.2019.1575830

Getchell, M. C., \& Sellnow, T. L. (2016). A network analysis of official Twitter accounts during the West Virginia water crisis. Computers in Human Behavior, 54, 597-606. https://doi.org/10.1016/j.chb.2015.06.044

Gintova, M. (2019). Understanding government social media users: an analysis of interactions on Immigration, Refugees and Citizenship Canada Twitter and Facebook. Government Information Quarterly, June, 101388. https://doi.org/10.1016/j.giq.2019.06.005

Gui, X., Kou, Y., Pine, K. H., \& Chen, Y. (2017). Managing uncertainty: Using social media for risk assessment during a public health crisis. Conference on Human Factors in Computing Systems - Proceedings, 2017-May, 45204533. https://doi.org/10.1145/3025453.3025891

Gundecha, P., \& Liu, H. (2012). Mining Social Media: A Brief Introduction. 2012 TutORials in Operations Research, Dmml, 1-17. https://doi.org/10.1287/educ.1120.0105

Hadi, T. A., \& Fleshler, K. (2016). Integrating Social Media Monitoring into Public Health Emergency Response Operations. Disaster Medicine and Public Health Preparedness, 10(5), $775-780$. https://doi.org/10.1017/dmp.2016.39

Harapan, H., Itoh, N., Yufika, A., Winardi, W., Keam, S., Te, H., Megawati, D., Hayati, Z., Wagner, A. L., \& Mudatsir, M. (2020). Coronavirus disease 2019 (COVID-19): A literature review. Journal of Infection and Public Health, 13(5), 667-673. https://doi.org/10.1016/j.jiph.2020.03.019

Himelboim, I., Smith, M. A., Rainie, L., Shneiderman, B., \& Espina, C. (2017). Classifying Twitter Topic-Networks Using Social Network Analysis. Social Media and Society, 3(1). https://doi.org/10.1177/2056305117691545

Ihsanuddin. (2020). Jokowi Larang Pemerintah Daerah Lakukan Lockdown Terkait Covid-19. Nasionanl.Kompas.Com. https:/nasional.kompas.com/read/2020/o3/16/15420291/jokowi-larang-pemerintah-daerah-lakukan-lockdownterkait-covid-19?page=all 
Jong, W., Dückers, M. L. A., \& van der Velden, P. G. (2016). Crisis Leadership by Mayors: A Qualitative Content Analysis of Newspapers and Social Media on the MH17 Disaster. Journal of Contingencies and Crisis Management, 24(4), 286-295. https://doi.org/10.1111/1468-5973.12124

Kim, J., \& Hastak, M. (2018). Social network analysis: Characteristics of online social networks after a disaster. International Journal of Information Management, 38(1), 86-96. https://doi.org/10.1016/j.ijinfomgt.2017.08.003

Kimmel, A. J., \& Kitchen, P. J. (2014). Word of mouth and social media. Journal of Marketing Communications. https://doi.org/10.1080/13527266.2013.865868

Lestari, P., Ritonga, R., Ruliana, P., \& Barus, C. C. B. (2020). Disaster communication uses field training exercise simulation as an important aspect of disaster risk reduction. Jurnal Komunikasi: Malaysian Journal of Communication, 36(1), 166-186. https://doi.org/10.17576/JKMJC-2020-3601-10

Linda Lai, \& To. (2015). Content Analysis of Social Media: A Grounded Theory Approach. Journal of Electronic Commerce Research, 16(2), 138-152.

Liu, B. F., Fraustino, J. D., \& Jin, Y. (2016). Social Media Use During Disasters: How Information Form and Source Influence Intended Behavioral Responses. Communication Research, 43(5), 626-646. https://doi.org/10.1177/0093650214565917

Machmuda, M., Musab, A. E. Z., \& Masmuhc, A. (2020). Government Response and Communication in Covid-19 Crisis Management in Indonesia. Ijicc.Net, 14(2), 377-396. https://www.ijicc.net/images/Vol_14/Iss_2/14226 _Machmud_2020_E_R.pdf

Muninger, M. I., Hammedi, W., \& Mahr, D. (2019). The value of social media for innovation: A capability perspective. Journal of Business Research, 95(July 2017), 116-127. https://doi.org/10.1016/j.jbusres.2018.10.012

Nazaruddin, M. (2020). Social media and alternative discourse on natural hazard: A case study of facebook group 'info merapi.' Jurnal Komunikasi: Malaysian Journal of Communication, 36(1), $480-494$. https://doi.org/10.17576/JKMJC-2020-3601-28

Nursing, A., \& Kyng, H. (2008). The qualitative content analysis process. Journal of Advanced Nursing, 62(1), $107-115$. https://doi.org/10.1111/j.1365-2648.2007.04569.x

Osterrieder, A. (2013). The value and use of social media as communication tool in the plant sciences. Plant Methods, 9(1). https://doi.org/10.1186/1746-4811-9-26

Panagiotopoulos, Panagiotis, Bigdeli, A. Z., \& Sams, S. (2014). Citizen-government collaboration on social media: The case of Twitter in the 2011 riots in England. Government Information Quarterly, 31(3), 349-357. https://doi.org/10.1016/j.giq.2013.10.014

Panagiotopoulos, Panos, Barnett, J., Bigdeli, A. Z., \& Sams, S. (2016a). Social media in emergency management: Twitter as a tool for communicating risks to the public. Technological Forecasting and Social Change, 111, 8696. https://doi.org/10.1016/j.techfore.2016.06.010

Panagiotopoulos, Panos, Barnett, J., Bigdeli, A. Z., \& Sams, S. (2016b). Social Media in Emergency Management: Twitter as a Tool for Communicating Risks to the Public. Technological Forecasting and Social Change, 111(October 2012), 1-27. https://doi.org/10.1016/j.techfore.2016.06.010

Pennycook, G., McPhetres, J., Zhang, Y., \& Rand, D. (2020). Fighting COVID-19 misinformation on social media: Experimental evidence for a scalable accuracy nudge intervention. PsyArXiv [Working Paper], 1-24. https://doi.org/10.31234/OSF.IO/UHBK9

Pickard G. Picard, V. P. (2017). Essential Principles for Contemporary Media and Communications Policymaking. Reuters Institute for the Study of Journalism: University of Oxford., April.

Pohl, D., Bouchachia, A., \& Hellwagner, H. (2015). Social media for crisis management: clustering approaches for sub-event detection. Multimedia Tools and Applications, 74(11), 3901-3932. https://doi.org/10.1007/s11042-0131804-2

Qazi, A., Raj, R. G., Hardaker, G., \& Standing, C. (2017). A systematic literature review on opinion types and sentiment analysis techniques: Tasks and challenges. Internet Research, 27(3), 608-630. https://doi.org/10.1108/IntR-04-2016-0o86

Reuter, C., Hughes, A. L., \& Kaufhold, M. A. (2018). Social Media in Crisis Management: An Evaluation and Analysis of Crisis Informatics Research. International Journal of Human-Computer Interaction, 34(4), $280-294$. https://doi.org/10.1080/10447318.2018.1427832

Roblek, V., Bach, M. P., Meško, M., \& Bertoncelj, A. (2013). The impact of social media to value added in knowledgebased industries. Kybernetes, 42(4), 554-568. https://doi.org/10.1108/K-01-2013-0014

Salahudin, S. et al. (2020). Analysis of Government Official Twitters during Covid-19 Crisis in Indonesia Analysis of Government Official Twitters during Covid-19 Crisis in Indonesia. Talent Development E Excellence, 12(June), 3899-3915. 
Saleh, R., \& Yusmanizar. (2019). Emergency response and communication during bili-bili dam flood crisis in Indonesia. Jurnal Komunikasi: Malaysian Journal of Communication, 35(4), 484-497. https://doi.org/10.17576/JKMJC-20193504-30

Setiati, S., \& Azwar, M. K. (2020). COVID-19 and Indonesia. Acta Med Indones - Indones J Intern Med, 52(1), 84-89.

Singh, L., Bansal, S., Bode, L., Budak, C., Chi, G., Kawintiranon, K., Padden, C., Vanarsdall, R., Vraga, E., \& Wang, Y. (2020). A first look at COVID-19 information and misinformation sharing on Twitter. http://arxiv.org/abs/2003.13907

Singh, P., Dwivedi, Y. K., Kahlon, K. S., Sawhney, R. S., Alalwan, A. A., \& Rana, N. P. (2020). Smart Monitoring and Controlling of Government Policies Using Social Media and Cloud Computing. Information Systems Frontiers, 22(2), 315-337. https://doi.org/10.1007/s10796-019-09916-y

Tempo. (2020). Karantina Wilayah Ditolak Jokowi, Anies Siapkan Masker Gratis. Tempo.Co. https://metro.tempo.co/read/1326281/karantina-wilayah-ditolak-jokowi-anies-siapkan-masker-gratis

Vos, S. C., \& Buckner, M. M. (2016). Social Media Messages in an Emerging Health Crisis: Tweeting Bird Flu. Journal of Health Communication, 21(3), 301-308. https://doi.org/10.1080/10810730.2015.1064495

Zeng, J., Chan, C. H., \& Fu, K. W. (2017). How Social Media Construct “Truth” Around Crisis Events: Weibo's Rumor Management Strategies After the 2015 Tianjin Blasts. Policy and Internet, 9(3), 297-320. https://doi.org/10.1002/poi3.155

Zhu, L., Anagondahalli, D., \& Zhang, A. (2017). Social media and culture in crisis communication: McDonald's and KFC crises management in China. Public Relations Review, 43(3), 487-492. https://doi.org/10.1016/j.pubrev.2017.03.006 